\title{
The use of molecular techniques in the taxonomy of water mites (Hydrachnidia, Acari)
}

\author{
ROBERT STRYJECKI, ${ }^{1}$ ALEKSANDRA BAŃKOWSKA, ${ }^{2}$ MAGDALENA GRYZIŃSKA, ${ }^{3}$ \\ EWA SARNACKA, ${ }^{2}$ MAGDALENA RUTKOWSKA, ${ }^{4}$ ANDRZEJ ZAWAL ${ }^{2}$
}

\footnotetext{
Department of Zoology, Animal Ecology and Wildlife Management, University of Life Sciences in Lublin, Akademicka 13, 20-950 Lublin, Poland; e-mail: robstry@wp.pl

2 Department of Invertebrate Zoology and Limnology, Institute for Research on Biodiversity, Faculty of Biology, University of Szczecin, Wąska 13, 71-415 Szczecin, Poland; e-mail: zawal@univ.szczecin.pl

3 Department of Biological Basis of Animal Production, University of Life Sciences in Lublin, Akademicka 13, 20-950 Lublin, Poland; e-mail: magdalena.gryzinska@up.lublin.p1

4 Department of Biochemistry, Faculty of Biology, University of Szczecin, Felczaka 3a, 71-412 Szczecin, Poland.
}

Keywords Molecular analysis, DNA barcoding, systematic revisions, taxonomic identification

Abstract The Hydrachnidia (water mites) are a robust component of aquatic communities in terms of both abundance and species richness. They have colonized all types of freshwater habitats and are highly diversified in both lotic and lentic habitats. Over 6,000 species of Hydrachnidia have been described worldwide, representing eight superfamilies, 57 families, 81 subfamilies and more than 420 genera. Water mite systematics is continually subject to change and various modifications. Performing systematic revisions can lead to numerous misunderstandings and difficulties in comparing research results, as the same species can have different systematic names in different publications. The development of molecular biology techniques has popularized the use of genomic traits in taxonomic identification. Among various markers used to identify species, the most important is the gene encoding cytochrome c oxidase I (COI). Species identification based on this gene is known as 'DNA barcoding'. The use of DNA barcoding was a breakthrough in molecular methods of species identification and has dominated research on invertebrates. It has become possible to identify not only new species, but also species that are difficult to distinguish using traditional methods. Water mites are organisms on which molecular analysis is still rarely performed, as compared to other groups of invertebrates. Fortunately, recent years have seen increasing use of molecular techniques to clarify the intricacies of Hydrachnidia taxonomy. Using DNA markers in the taxonomy of water mites enables definitive resolution of ambiguities in the case of numerous questionable taxa, which is of great importance in all other types of research on these organisms.

\footnotetext{
Wykorzystanie technik molekularnych w taksonomii wodopójek (Hydrachnidia, Acari)

Słowa kluczowe analizy molekularne, DNA barcoding, rewizje systematyczne, identyfikacja gatunków

Streszczenie Wodopójki (Hydrachnidia) są istotnym komponentem zgrupowań bezkręgowców wodnych zarówno pod względem liczebności, jak i bogactwa gatunkowego. Organizmy te skolonizowały wszelkie rodzaje siedlisk wodnych. Zróżnicowana fauna Hydrachnidia występuje zarówno
} 
w wodach stojących, jak i płynących. Dotychczas opisano na świecie ponad 6 tys. gatunków, reprezentujących dziewięć nadrodzin, 57 rodzin, 81 podrodzin i ponad 420 rodzajów. Systematyka wodopójek ulega ciągłym zmianom i różnym modyfikacjom. Przeprowadzanie częstych rewizji w systematyce Hydrachnidia może prowadzić do wielu nieporozumień i trudności przy porównywaniu wyników, ponieważ te same gatunki mogą występować w różnych publikacjach pod różnymi nazwami. Rozwój technik molekularnych spopularyzował wykorzystanie cech genomu przy identyfikacji gatunków. Spośród różnych markerów stosowanych przy identyfikacji poszczególnych gatunków największe znaczenie ma gen oksydazy I cytochromu c (COI). Identyfikacja gatunkowa w oparciu o ten gen nazywa się "DNA barcoding". Zastosowanie tzw. metkowania genetycznego (DNA barcoding) stanowiło przełom w molekularnych metodach identyfikacji gatunków i zdominowało badania bezkręgowców. Możliwa stała się nie tylko identyfikacja nowych gatunków, ale także gatunków, które trudno rozróżnić metodami tradycyjnymi. Wodopójki są organizmami, u których wciąż rzadko przeprowadza się analizy molekularne. Jednak w ostatnich latach można zauważyć coraz częstsze zastosowanie tych technik w taksonomii Hydrachnidia. Wykorzystanie markerów DNA w taksonomii wodopójek pozwala na ostateczne wyjaśnienie przynależności taksonomicznej wątpliwych gatunków, co ma ogromne znaczenie we wszelkich badaniach nad tymi organizmami.

\section{Introduction}

Acari (mites and ticks) are an exceptionally diverse group of Arachnida (Chelicerata) in terms of both form and life strategies. The approximately 50,000 named species represent only a small fraction of the actual taxonomic diversity, which is sometimes estimated at more than one million species (Alberti 2006). Most Acari inhabit terrestrial environments, but some have also adapted to living in aquatic ecosystems. Among the mites best adapted to living in an aquatic environment are water mites (Hydrachnidia).

The Hydrachnidia (water mites) represent the most important group of Arachnida in freshwater. They are a robust component of aquatic communities in terms of both abundance and species richness (Di Sabatino et al. 2000; 2008). Water mites have colonized all types of freshwater habitats and are highly diversified in both lotic and lentic habitats. Samples from $1 \mathrm{~m}^{2}$ of substratum in running water riffles may contain up to 5,000 individuals, belonging to more than 50 species and 30 genera (Smith et al. 2001). Over 6,000 species of Hydrachnidia have been described worldwide, representing eight superfamilies, 57 families, 81 subfamilies and more than 420 genera (Viets 1987; Smit 2009). These numbers are certainly not final. An estimated 5,500 may occur in the Neotropics alone, and more than 10,000 species could reasonably be expected to occur in inland waters worldwide (Goldschmidt 2002; Di Sabatino et al. 2008).

Water mites, together with three other lineages (the terrestrial Erythraiae and Trombidiae and the aquatic Stygothrombiae), make up the hyporder Parasitengona, which is characterized by parasitic larvae and predatory nymphs and adults (Dabert et al. 2016). The derivation of Hydrachnidia from terrestrial Parasitengona was confirmed by molecular testing of the phylogenesis of acariform mites (Dabert et al. 2010; 2016).

The most important works compiling knowledge of water mite systematics include the global taxonomic catalogues and bibliographies of Viets (1956) and Viets (1982; 1987). However, the most important taxonomic work is the identification key by Cook (1974) for world genera and subgenera. There are also keys available for identification of the water mites of various regions of the world, as well as some taxonomic works which are of great help in identifying local faunas (see Di Sabatino et al. 2000 for literature). 


\section{Problems and ambiguities in Hydrachnidia systematics}

Correct taxonomic identification of organisms is of great importance at each level of the natural sciences, from ecology to proteomics and genomics (Wheeler et al. 2004; Wilson 2004; Wheeler \& Valdecasas 2007). Precise and accurate nomenclature of taxa is essential in building a knowledge base and is of fundamental significance for science. This postulate cannot always be met, as many species show varying degrees of intraspecific variation, which may be geographically structured, and species delimitation is not always straightforward (Sites \& Marshall 2003; 2004). Moreover, the many traits that vary within populations and species lead to an abundance of irrelevant, uninformative and misleading information (Wheeler \& Valdecasas 2007).

Water mite systematics, as in the case of other organisms, is continually subject to change and various modifications. For example, most authors agree with the division of the eight superfamilies of water mites into two groups - the lower water mites (superfamilies Stygothrombidioidea, Hydrovolzioidea, Hydrachnoidea, Eylaoidea and Hydryphantoidea) and more highly evolved mites (superfamilies Lebertoidea, Hygrobatoidea and Arrenuroidea); however, alternative superfamily and family classifications have been proposed by Tuzowskij (1987), Witte (1991) and Harvey (1998). The use of multiple molecular markers to study higher-level molecular phylogeny of water mites has strongly supported all commonly accepted water mite superfamilies except for Hydryphantoidea, which is clearly paraphyletic. These data support the previously proposed clades Protohydrachnidia (Hydrovolzioidea and Eylaoidea) and Euhydrachnidia (all remaining superfamilies), as well as the euhydrachnid subclade Neohydrachnidia (Lebertioidea, Hydrachnoidea, Hygrobatoidea, and Arrenuroidea) (Dabert et al. 2016)

Performing systematic revisions can lead to numerous misunderstandings and difficulties in comparing research results, as the same species can have different systematic names in different publications. For example, according to a list of water mites of Poland (Biesiadka 2008), 45 species of the genus Lebertia have been recorded in the country. However, according to the latest systematic revisions for the genus Lebertia (Gerecke 2009), the number of species of this genus recorded in Poland is only 26, as 19 species have been synonymized. A similar example can be cited for the genus Atractides. The list of water mites of Poland includes 34 species of this genus, but according to Gerecke (2003), many of these taxa are questionable or can be synonymized with other species. If we take into account the revision by Gerecke (2003), the number of species of the genus Atractides recorded in Poland is reduced from 34 to 25. These examples demonstrate that standardization of nomenclature is essential, as without unified species nomenclature faunistic and ecological studies, even in adjacent geographical regions, cannot be compared. Moreover, the use of different names for de facto the same species can lead to numerous misunderstandings and erroneous interpretation of results, the ecological status of species, their ranges, and other data on their biology.

Sometimes difficulties are encountered in recognition of species that would seem to be easy to identify. For example, Davids and Kouwets (1987) faced a number of problems in identification of species of the genus Piona. To resolve the difficulties in identifying adult forms of water mites, the authors largely relied on the morphology of the larvae, on the assumption that water mite larvae appear to be much less morphologically variable than adult forms and are therefore taxonomically useful in distinguishing closely related taxa (Prasad \& Cook 1972). A similar problem occurs in the case of the genus Eylais, in which the considerable variability of morphological characters in adult forms created substantial difficulties in describing and recognizing species, whereas the morphological characters of the larvae are well defined and much more constant. 
In effect, different systematics have arisen within this genus (Davids et al. 2007). In Piona coccinea (Koch, 1836) a number of subspecies have been described (Viets 1956). The distinction between adults of $P$. coccinea and $P$. stjordalensis was never a significant problem, but there have been some difficulties in distinguishing between $P$. coccinea and $P$. coccinea imminuta (Piersig 1987), as $P$. coccinea specimens that have lost their red colour in the preservation fluid could be mistakenly identified as the form $P$. coccinea imminuta (Davids \& Kouwets 1987). Davids and Kouwets (1987) cleared up the ambiguities regarding the P. coccinea complex; on the basis of measurements of adult individuals and shape of the claw of the male third leg and larvae they determined that we are dealing with three species: $P$. coccinea, $P$. imminuta and $P$. stjordalensis. They also established clear differences between the larvae of $P$. coccinea imminuta and $P$. coccinea. In the past some authors had distinguished only two species in this complex (P. coccinea and P. stjordalensis) (Biesiadka 1977).

According to a well-known principle, a species and its separate subspecies cannot co-occur (Mayr 1969). Therefore cases of the co-occurrence of a species and subspecies in one water body suggest that the subspecies should be recognized as a separate species. Such cases have been noted in the past, e.g. in the case of Piona pusilla and Piona pusilla rotundoides, or Piona coccinea and Piona coccinea imminuta (Davids \& Kouwets 1987). In these two examples, the subspecies were fairly quickly recognized as separate species (Davids \& Kouwets 1987). However, other examples can be cited, such as Piona variabilis and Piona variabilis dispersa, whose taxonomic status is still unclear; some authors argue that Piona variabilis is a separate species, and it is identified as such in species lists and in some identification keys (Biesiadka 2008; Stålstedt et al. 2013; Gerecke et al. 2016), while in other registers it is listed as a subspecies (Smit \& Van der Hammen 2000; Smit 2009). In such questionable cases modern methods for identifying organisms, i.e. molecular techniques, can be very useful.

\section{The use of molecular techniques in taxonomy}

The development of molecular biology techniques has popularized the use of genomic traits in taxonomic identification. The most important characteristic of a DNA molecule is the order of the nucleotides contained in it, which is subject to selection pressure. The advantages of using DNA in this type of analysis are the vast amount of input data and the ease of numerical description and creation of a mathematical model of their evolution. Taxonomic analyses are based on the nuclear genome (nDNA) and the mitochondrial plasmid (mtDNA). In the case of analyses based on the nuclear genome, we are dealing with biparental inheritance (in equal parts from the father and mother), while analyses using mitochondrial DNA involve uniparental inheritance (only in the maternal line). In the case of Hydrachnidia, analyses are based on the nuclear genome (nDNA) (Dabert et al. 2008; Mahdieh et al. 2012).

Among various markers used to identify species, the most important is the gene encoding cytochrome c oxidase I (COI). Species identification based on this gene is known as 'DNA barcoding'. A fragment of about 650 nucleotides of the COI gene is used for the analysis. The COI sequence is characterized by low intra-species variability and high inter-species variability (Hebert et al. 2003). The use of DNA barcoding was a breakthrough in molecular methods of species identification and has dominated research on invertebrates (Hebert et al. 2003). It has become possible to identify not only new species, but also species that are difficult to distinguish using traditional methods. The COI gene fragment served as evidence for species separation in water mites such as Hygrobates nigromaculatus and H. setosus (Martin et al. 2010), a few representatives of mites 
of the superfamilies Hygrobatoidea and Arrenuroidea (Smit et al. 2015), and phylogenetic analysis of representatives of Acariformes (Dabert et al. 2010) and Hygrobatidae (Mahdieh et al. 2012).

Other molecular biology techniques, such as RAPD (random amplified polymorphic DNA), can be regarded as outdated. RAPD is still used in some research, but has limited application in establishing relationships between water mite populations (Edwards et al. 2004).

\section{Laboratory techniques}

\section{DNA extraction, amplification and sequencing}

Currently DNA isolation from such small organisms as water mites does not cause significant problems. After the organisms are caught and selected, genetic material can be extracted using ready-made sets of reagents. Initially, preliminary preparation of the biological material involved pulverization of whole water mites to a uniform mass (in a mortar), followed by suspension of the uniform cell mass in a suitable buffer. This resulted in destruction of outer membranes and release of DNA together with intracellular components. Currently DNA is isolated from mites by a non-invasive method, enabling the animal's morphology to be described later. Next a salt solution is added, usually $\mathrm{NaCl}$, containing Tris and EDTA. Addition of the enzyme proteinase $\mathrm{K}$ (protease $\mathrm{K}$ ) is essential. Proteinase $\mathrm{K}$ deactivates nucleases which could degrade DNA, and at the same time digests and removes protein contaminants during the DNA extraction process. In the next step, DNA is separated from the other cellular components. This stage is very important, because inadequate separation of DNA from proteins can lead to the lack of a DNA amplification product during the polymerase chain reaction (PCR). Proper isolation of DNA (in terms of both purity and concentration) is critical for further analytical procedures. For the purpose of further analyses, the isolated DNA should be amplified. Amplification during PCR is performed on a particular DNA fragment (usually ranging from 400 to 800 base pairs), and not the entire genome. PCR enables amplification in vitro conditions of selected DNA sequences. It is a highly sensitive method; quantities of DNA measured in picograms are sufficient for the reaction. This is a major advantage, as DNA from just a single cell can be amplified.

In vitro PCR is based on the process of DNA replication in vivo. DNA polymerase uses single stranded DNA (ssDNA) as a template for synthesis of a complementary strand. Single-stranded template DNA is obtained by heating a sample containing double-stranded DNA (dsDNA) to a temperature above $90{ }^{\circ} \mathrm{C}$ (this is the denaturation step). DNA polymerase, in order to initiate synthesis of new strands in the 5 ' $\rightarrow 3^{\prime}$ direction, requires free $3^{\prime}$ ends. These come from oligonucleotide primers. Primers bind specifically to single-stranded template DNA at complementary sites (the annealing step). Primers anneal to both strands of the template DNA, and are selected so as to enclose the DNA segment to be amplified. In the next step (elongation), DNA polymerase synthesizes new complementary strands on both strands of template DNA in two opposite directions, using dNTP contained in the reaction mixture. When the cycle is completed the strands are separated again (denaturation) to once again enable binding of the DNA template with the primer (annealing) and primer elongation. In each cycle the number of molecules of amplified DNA is doubled. The cycles are repeated many times, and after $n$ cycles $2^{\mathrm{n}}$ selected fragments of dsDNA are obtained, which are copies of the sequence contained between the primers.

The amplification product obtained can be sequenced, which involves reading the sequence, i.e. the order of nucleotide pairs in the DNA molecule. 
Sequencing is performed using automatic sequencers. Appropriate computer software generates the order of nucleotides on both DNA strands in the fragment analysed.

\section{Sequence and phylogenetic analyses}

Once we have obtained the nucleotide sequence in the DNA we can identify sequences related to it. By 'related' we mean that the sequences are similar enough that we can conclude that they have a common origin, i.e. are derived from a common ancestor. The simplest method for finding related sequences is to search computer databases using suitable software. One of the most popular is BLAST (Basic Local Alignment Search Tool), which enables comparison of a given sequence with sequences contained in biological databases and evaluation of their similarity.

Nucleotide sequence alignment is performed in order to identify regions exhibiting similarity, which could be due to functional, structural or evolutionary connections between taxa. Alignments are often presented both graphically and as text.

\section{Examples of the use of molecular techniques in resolving taxonomic doubts in Hydrachnidia}

\section{Hygrobates nigromaculatus and $\mathrm{H}$. setosus}

Hygrobates nigromaculatus Lebert, 1879 is recorded as a common European species living in both lakes and streams (see Martin et al. 2010 for literature). However, the species status of ' $H$. nigromaculatus' from these two habitat types has been questioned in the past. Besseling (1942) used measurements to distinguish different morphotypes in H. nigromaculatus sensu lato: one corresponding to the lake-dwelling H. nigromaculatus nigromaculatus sensu Besseling and the other to H. nigromaculatus setosus Besseling from running waters. In addition to morphological differences, some authors have pointed out important differences in the life-cycle strategies of $H$. nigromaculatus inhabiting different habitats: mites from stream-dwelling populations have a parasitic larva, whereas those of lake-dwelling populations have lost their larval parasitism (Martin \& Davids 2002; Martin et al. 2010).

The older literature contains several descriptions of Hygrobates nigromaculatus larvae (Ullrich 1976; Wainstein 1980; Van Hezewijk \& Davids 1985). However, after the discovery that only Hygrobates setosus has a parasitic larva in its life cycle, while there is no parasitic phase in H. nigromaculatus (Martin \& Davids 2002; Martin et al. 2010), it should be concluded that descriptions of $H$. nigromaculatus larvae are de facto descriptions of the larvae of $H$. setosus. A study by Martin et al. (2010) contains a biometric comparison of the parasitic larva of $H$. setosus and the non-parasitic larva of $H$. nigromaculatus. Thus differences were observed in populations of $H$. nigromaculatus sensu lato inhabiting standing and flowing water based on measurements of individuals from these two environments, as well as on life cycle differences, but doubts concerning the taxonomic status of this species were ultimately resolved only after molecular analysis.

Martin et al. (2010) demonstrated that the Hygrobates nigromaculatus complex consists of two separate species by providing molecular evidence for their separation. Their results indicate that populations inhabiting lakes and streams should be ranked at the species level: as H. nigromaculatus Lebert, 1897 from lakes and H. setosus Besseling, 1942 nov. stat. from streams. 


\section{Piona variabilis and $P$. dispersa}

Piona variabilis (Koch, 1836) and Piona variabilis dispersa Sokolow, 1926 are another example of a situation in which it is unclear whether we are dealing with two species or with a species and subspecies. Piona dispersa had usually been treated as a synonym of the nominate species P. variabilis (Smit 2009; Gerecke 2011). However, for many years there were no detailed taxonomical studies and $P$. dispersa was inconsistently treated as a synonym, a form, or a species (Lundblad 1962; Böttger \& Ullrich 1974). Böttger and Ullrich (1974) believed these two taxa to be conspecific, and $P$. dispersa was originally described as a variety of $P$. variabilis due to its unsclerotized genital acetabula in females and no distinguishing features between the males of the two species (Sokolow 1926). Some authors (Biesiadka 2008) considered Piona dispersa to be a separate species.

Stålstedt et al. (2013) performed molecular analyses of a few closely related water mite taxa, including Piona variablilis and $P$. dispersa. The results of the molecular analyses (barcoding analyses of COI) showed a genetic distance of $11 \%$ between these two species. The molecular and morphological data indicate that Piona dispersa is a valid species, separated from the nominate species $P$. variabilis (Stålstedt et al. 2013)

\section{Species of the Piona nodata-complex}

Four species can be included in the Piona nodata complex: P. nodata (Müller, 1776), P. ambigua (Piersig, 1894), P. laminata (Thor, 1901) and P. annulata (Thor, 1901). These species were extensively studied by Lunblad (1962), but for many years afterwards there was a certain disorder in the literature, as different authors treated these species in different ways, usually as subspecies within Piona nodata (e.g. P. nodata laminata), or without distinguishing them from Piona nodata at all (Biesiadka 2008; Smit \& Van der Hammen 2000; Smit 2009). Until detailed molecular analysis was conducted, erroneous identifications occurred as well, even in fairly recent literature (Smit \& Van der Hammen 2000; Smit \& Gerecke 2010). Molecular data show that Piona laminata and $P$. nodata from the Netherlands differ at a level of $15.57 \%$, clearly indicating that they are separate species (Smit et al. 2015). Apart from molecular analyses, Smit et al. (2015) also report morphological characters based on which the four species once considered to be the Piona nodata-complex can be distinguished. The latest key for identification of European Hydrachnidia (Gerecke et al. 2016) provides diagnostic characters owing to which these species can easily be distinguished.

\section{Using molecular methods to describe predator-prey relationships}

Molecular techniques can be used not only to resolve taxonomic ambiguities, but also in ecology, e.g. to describe predator-prey relationships (Martin et al. 2015). The authors cited were able to detect chironomid DNA in water mite bodies for the first time using molecular methods. Prey DNA was detected in virtually all Hygrobates fluviatilis (Hygrobatidae) that were fed on chironomid larvae. From the shortest interval ( $1 \mathrm{~h}$ after feeding) to the longest period after feeding $(50 \mathrm{~h})$ the relative amount of prey DNA detected was significantly reduced. The results of this study indicate that similar molecular analyses will be a powerful tool for investigations of the diet of water mites. Moreover, the results of food selection experiments from the laboratory could be compared to evidence of predation by individuals from the field. For many mite taxa, 
especially those which have proved difficult to breed in the laboratory (e.g. because their diet is unknown), the new methods might provide us with the first ever data on diet and thus improve our understanding of the role of water mites in food webs in the future (Martin et al. 2015).

\section{Conclusions}

Classical descriptive taxonomy has been criticized for being subjective and overly 'descriptive' (Wheeler \& Valdecasas 2007). Owing to the appearance of modern methods exploiting molecular techniques in taxonomy, both of these criticisms can be considered obsolete. Modern techniques make it possible to establish whether we are dealing with intraspecific variation or separate species (Stålstedt et al. 2013).

Water mites are organisms on which molecular analysis is still rarely performed, as compared to other groups of invertebrates. Fortunately, recent years have seen increasing use of molecular techniques to clarify the intricacies of Hydrachnidia taxonomy (Martin et al. 2010; Mahdieh et al. 2012; Stålstedt et al. 2013; Smit et al. 2015; Martin et al. 2015). Using DNA markers in the taxonomy of water mites enables definitive resolution of ambiguities in the case of numerous questionable taxa, which is of great importance in all other types of research on these organisms. An important work by Dabert et al. (2016) on higher-level molecular phylogeny of water mites, based on the use of multiple molecular markers, provides a strong framework for classification of water mites and for further elaboration of their relationships at finer taxonomic scales.

\section{References}

Alberti G. 2006. On some fundamental characteristics in acarine morphology. Atti della Accademia Nazionale Italiana di Entomologia. Rendiconti, 53: 315-360.

Besseling A.J. 1942. Nederlandsche Hydrachnidae. Genus Hygrobates. Entomol. Ber., 11 (243): 2-6.

Biesiadka E. 1977. Sur la position systématique de Piona coccinea (Koch, 1836) et Piona stjördalensis (Thor, 1897). Bull. Acad. Sci. Pol., Ser. Sci Biol. Cl. II, 24: 735-740.

Biesiadka E. 2008. Water Mites (Hydrachnidia). In: Fauna of Poland-characteristics and check-list of species, W. Bogdanowicz, E. Chudzicka, I. Pilipiuk, E. Skibińska (eds). Muzeum i Instytut Zoologii PAN, Warszawa, pp. 149-219.

Böttger K., Ullrich F. 1974. Wassermilben (Hydrachnellae, Acari) der Eider, Faunistische und biologischökologische Angaben. Faun.-ökol. Mitt., 4: 419-436.

Cook D.R. 1974. Water mite genera and subgenera. Mem. Am. Entomol. Inst., 21: 1-860.

Dabert J., Ehrnsberger R., Dabert M. 2008. Glaucalges tytonis sp. n. (Analgoidea, Xolalgidae) from the barn owl Tyto alba (Strigiformes, Tytonidae): compiling morphology with DNA barcode data for taxon descriptions in mites (Acari). Zootaxa, 1719: 41-52.

Dabert M., Proctor H., Dabert J. 2016. Higher-level molecular phylogeny of the water mites (Acariformes: Prostigmata: Parasitengonina: Hydrachnidiae). Molecular Phylogenetics and Evolution, 101: 75-90.

Dabert M., Witaliński W., Kazmierski A., Olszanowski Z., Dabert J. 2010. Molecular phylogeny of acariform mites (Acari, Arachnida): Strong conflict between phylogenetic signal and long-branch attraction artifacts. Mol. Phylogen. Evol., 56: 222-241.

Davids C., Di Sabatino A., Gerecke R., Gledhill T., Smit H., Van der Hammen H. 2007. Acari: Hydrachnidia I. In: Süßwasserfauna von Mitteleuropa, R. Gerecke (ed.), Elsevier GmbN, Spektrum Akademischer Verlag, München, pp. 241-376. 
Davids C., Kouwets F.A.C. 1987. The characteristics of some water mite species of the genus Piona (Acari, Hydrachnellae) with three new larval descriptions. Arch. Hydrobiol., 110 (1): 1-18.

Di Sabatino A., Gerecke R., Martin P. 2000. The biology and ecology of lotic water mites (Hydrachnidia). Freshwat. Biol., 44: 47-62.

Di Sabatino A., Smit H., Gerecke R., Goldschmidt T., Matsumoto N., Cicolani B. 2008. Global diversity of water mites (Acari, Hydrachnidia; Arachnida) in freshwater. Hydrobiologia, 595: 303-315.

Edwards D.D., Deatherage D.E., Ernsting B.R. 2004. Random amplified polymorphic DNA analysis of kinship within host-associated populations of the symbiotic water mite Unionicola foili (Acari: Unionicolidae). Exp. Appl. Acarol., 34: 67-77.

Gerecke R. 2003. Water mites of the genus Atractides Koch, 1837 (Acari: Parasitengona: Hygrobatidae) in the western Palaearctic region: a revision. Zool. J. Lin. Soc-Lon, 138 (2-3): 141-378.

Gerecke R. 2009. Revisional studies on the European species of the water mite genus Lebertia Neumann, 1880 (Acari: Hydrachnidia, Lebertiidae). Abh. Senckengberh Ges. Naturforsch., 566: 1-144.

Gerecke R. 2011. Fauna Europaea: Pionidae, Unionicolidae. In: Fauna Europaea: Acari, W. Magowski (ed), Fauna Europaea version 2.4. Available at: http://www.faunaeur.org/.

Gerecke R., Gledhill T., Pešić V., Smit H. 2016. Chelicerata: Acari III. In: Süßwasserfauna von Mitteleuropa, R. Gerecke (ed.), Bd. 7/2-3, pp. 1-429.

Goldschmidt T. 2002. The biodiversity of Neotropical water mites. In: Acarid Phylogeny and Evolution. Adaptations in mites and ticks, F. Bernini, R. Nannelli, G. Nuzzaci, F. de Lillo (eds.), Springer Science + Busines Media, Dordrecht, pp. 91-99.

Harvey M.S. 1998. The Australian Water Mites. A Guide to Families and Genera. Monographs on Invertebrate Taxonomy, 5: 1-150.

Hebert P.D.N., Cywinska A., Ball S.L, deWaard J.R. 2003. Biological identifications through DNA barcodes. Proc. R. Soc. Lond. B, 270: 313-321.

Lundblad O. 1962. Die Hydracarinen Schwedens II. Arkiv för Zoologi, 14: 1-635.

Mahdieh A., Hinomoto N., Saboori A, Javan-Nikkhah M. 2012. Genetic diversity in mitochondrial cytochrome coxidase subunit I sequences of the water mite Hygrobates fluviatilis (Acari: Hydrachnidia: Hygrobatidae). Int. J. Acarol., 38 (2): 96-100.

Martin P., Davids C. 2002. Life history strategies of Hygrobates nigromaculatus, a widespread Palaearctic water mite (Acari, Hydrachnidia, Hygrobatidae). In: Acarid Phylogeny and Evolution. Adaptations in mites and ticks. F. Bernini, R. Nannelli, G. Nuzzaci, F. de Lillo (eds.). Springer Science + Busines Media, Dordrecht, pp. 101-110.

Martin P., Dabert M., Dabert J. 2010. Molecular evidence for species separation in the water mite Hygrobates nigromaculatus Lebert, 1879 (Acari, Hydrachnidia): evolutionary consequences of the loss of larval parasitism. Aquat. Sci., 72: 347-360.

Martin P., Koester M., Schynawa L., Gergs R. 2015. First detection of prey DNA in Hygrobates fluviatilis (Hydrachnidia, Acari): a new approach for determining predator-prey relationships in water mites. Exp. Appl. Acarol., 67 (3): 373-80.

Mayr E. 1969. Principles of systematic zoology. McGraw-Hill, New York, p. 428.

Prasad V., Cook D.R. 1972. The Taxonomy of water mite larvae. Mem. Amer. Ent. Inst., 18: 1-326.

Sites J.W., Marshall J.C. 2003. Delimiting species: a renaissance issue in systematic biology. Trends Ecol. Evol., 18: 462-470.

Sites J.W., Marshall J.C. 2004. Operational criteria for delimiting species. Annu. Rev. Ecol. Evol. Syst., 35: 199-227. 
Smit H. 2009. European Water Mite Research. European Water Mite Fauna (new Entries), A Checklist of the Water Mites Inhabiting European Inland Waters. Available at: http://www.watermite.org/.

Smit H., Van der Hammen H. 2000. Atlas van de Nederlandse watermijten. Nederlandse Faunistische Mededelingen, 13: 1-272.

Smit H., Gerecke R. 2010. A checklist of the water mites of France (Acari: Hydrachnidia). Acarologia, 50 (1): 21-91.

Smit H., Gerecke R., Pešić V., Gledhill T. 2015. On the taxonomic state of water mite taxa (Acari: Hydrachnidia) described from the Palaearctic, part 3, Hygrobatoidea and Arrenuroidea with new faunistic data. Zootaxa, 3981 (4): 542-552.

Smith I.M., Cook D.R., Smith B.P. 2001. Water mites (Hydrachnida) and other arachnids. In: Ecology and Classification of North American Freshwater Invertebrates (2nd ed.), J.H. Thorp, A.P. Covich (eds.). Academic Press, San Diego, California, pp. 51-659.

Sokolow I. 1926. Neue Hydracarien aus Russisch-Karelien. Russ. Entomol. Obozr., 3-4: 165-179.

Stålstedt J., Bergsten J., Ronquist F. 2013. "Forms" of water mites (Acari: Hydrachnidia): intraspecific variation or valid species? Ecol. Evol., 3 (10): 3415-3435.

Tuzovskij P.V. 1987. Morphology and postembryonal development of water mites. Nauka, Moscow, pp. 1-176.

Ullrich F. 1976. Biologisch-ökologische Studien an rheophilen Wassermilben (Hydrachnellae, Acari), unterbesonderer Berücksichrigung von Sperchon setiger (Thor 1898). PhD. thesis, Univ. of Kiel, pp. 1-241.

Van Hezewijk M.J., Davids C. 1985. The larvae of three water mite species of the genus Hygrobates and their development (Acari, Hydrachnellae). B Zool. Mus. Univ. Amsterdam, 10: 97-105.

Viets K. 1956. Die Milben des Süßwassers und des Meeres. Hydrachnellae et Halacaridae (Acari). II, III. Teil: Katalog und Nomenklator. Gustav Fischer-Verlag, Jena, pp. 1-870.

Viets K.O. 1982. Die Milben des Süßwassers (Hydrachnellae und Halacaridae [part.], Acari). 1. Bibliographie. Sonderbände Des Naturwissenschaftlichen Vereins in Hamburg, 6, pp. 1-116.

Viets K.O. 1987. Die Milben des Süßwassers (Hydrachnellae und Halacaridae [part.], Acari). 2. Katalog. Sonderbände Des Naturwissenschaftlichen Vereins in Hamburg, 8, pp. 1-1012.

Wainstein, B.A. 1980. Opredelitel lichinok vodjanych kleshchei. Inst. Biol. Vnutrenn. Vod., Nauka, pp. 1-238.

Wheeler Q.D., Raven P.H., Wilson E.O. 2004. Taxonomy: impediment or expedient? Science, 303: 285.

Wheeler Q.D., Valdecasas A.G. 2007. Taxonomy: Myths and Misconceptions. Anales Jard. Bot. Madrid, 64 (2): $237-241$.

Wilson E.O. 2004. Taxonomy as a fundamental discipline. Phil. Trans. R. Soc. Lond. B, 359, 739.

Witte H. 1991. The phylogenetic relationships within the Parasitengona. In: Modern Acarology 2. F. Dusbabek, V. Bukwa (eds.). Academia Prague and SPB publ. The Hague, pp. 171-182.

Cite as: Stryjecki R., Bańkowska A., Gryzińska M., Sarnacka E., Rutkowska M., Zawal A. 2016. The use of molecular techniques in the taxonomy of water mites (Hydrachnidia, Acari). Acta Biologica, 23: 117-126. DOI: $10.18276 / \mathrm{ab} .2016 .23-10$. 